\title{
The Influence of STEM-Integrated 7E Learning Cycle on Students' Creative Thinking Skills in The Topic of Temperature and Heat
}

\author{
Parno $^{1 *}$, Lia Yuliati ${ }^{1}$, Edi Supriana ${ }^{1}$, Ahmad Taufiq $^{1}$, Marlina Binti Ali ${ }^{2}$, Anula Ning \\ Widarti $^{1}$, and Umi Azizah ${ }^{1}$ \\ *parno.fmipa@um.ac.id \\ Physics Education, Universitas Negeri Malang, Indonesia ${ }^{1}$ \\ Department of Educational Science, Universiti Teknologi Malaysia, Malaysia ${ }^{2}$
}

\begin{abstract}
This research purposes to study the influence of 7E LC-STEM on students' creative thinking skills in the temperature and heat topic using quasi-experiment research with Pre- and Posttest Design. The subject is students of Senior High School Batu Indonesia. They are distributed in the experiment (7E LC-STEM) and the comparison (7E LC) classes The research instrument is students' Creative Thinking Skills Test with reliability of Cronbach's alpha of 0.803 . The data is analyzed with t-test, N-gain, and effect size. The result shows that the STEM approach can increase creative thinking skills as indicated by the significantly higher average skill score obtained by the experiment class. The implementation effect of 7E LC-STEM learning has a very large category than 7E LC class in increasing creative thinking skills of students. The students of experiment class give higher positive responses than the comparison class for the learning process.
\end{abstract}

Keywords: 7E Learning Cycle, STEM, Creative Thinking Skills, Temperature, Heat

\section{Introduction}

Temperature and Heat is a topic in Physics which covers one of the most principal knowledge about nature relating to warmth and cold, which is relevant to the example of concrete daily activity and technology. However, this topic is still considered difficult by students and teachers in physics learning [1]. Students know no distinction between the two separate concepts, which are the concept of temperature and the concept of heat [2]. Students also thought that heat as an entity that can be materialized [3]. Other misconception is that the assumption that the bigger an object's mass, then the bigger its temperature [4]. Some still believe that if different objects are placed in a same environement for a long time, the objects will have different magnitude of temperature [5]. This may be due to the fact that teacher are only teaching lessons theoretically without trying to involve students in an active effort to explore and find the knowledge about temperature and heat on their own [6]. Moreover, students discovered that they can use mathematical equations on both topics to solve a problem, but they don't understand the concepts behind them well [2]. These issues affect students' ways to think creatively to solve a problem [7]. 
Creative thinking skills (CTS) are needed to face the obstacles of problem-solving in the globalization era of the 21 st century [8]. CTS are one of the skills in the century which are currently aimed as a focus in the field of education all over the world [9]. However, initial research showed that $63.71 \%$ of students still have a low level of CTS [10]. There are some learning models that have been implemented to increase students' creative thinking skills. Cognitive-Based Creativity Training was able to enhance students' CTS [11]. The generative learning was able to increase students' CTS in the heat transfer concept [12]. In the topic of Black's principle, Macromedia Flash technology was utilized with Problem-Based Learning to increase students' CTS with positive result [13]. However, learning which emphasizes conceptual understanding is still limited, so that CTS development has not yet been optimized. There's still room for improvement by using other learning models in an attempt to improve CTS of students in the Temperature and Heat topic.

The Temperature and Heat concept can be considered as abstract in nature with some mathematical equations in the mix, which can be utilized by students as the foundation to think creatively in understanding and applying relevant technology in daily activities. This characteristic can be covered by 7E Learning Cycle (7E LC), which is a learning model that consider students' initial knowledge about a concept to help them gather new information to complete or deepen their understanding about the topic [14]. This kind of activity has the potential to help students train their 21st-century skills, including CTS [15]. However, it's known that in every phase of $7 \mathrm{E} \mathrm{LC}$, students are still having difficulties in connecting existing concepts in physics to the newly acquired knowledge [16]. There is a way for students to develop their physics knowledge in an integrated manner through learning which connects physics concepts with real-world phenomenon's [17]. This motivated the integration of Science, Technology, Engineering, and Mathematics (STEM) into 7E LC to enhance students' CTS in the Temperature and Heat topic. It can be said that the 7E LC-STEM learning is oriented towards constructivist theory, albeit being rarely implemented in a real class setting.

As stated before, education in the 21st century is focused on, amongst other things, the development of CTS [9]. STEM is one of the approaches suitable in order to attain the highest level of skills in the 21st century [18]. STEM is also needed in physics learning [19]. To provide solutions to every day's contextual problems, STEM puts the utmost importance in the process of creative thinking where students aspire to solve the problems completely by working together in groups [20]. STEM integrates the aspect of Science, Technology, Engineering, and Mathematics in unison [21] so that students' knowledge and skills can develop in a comprehensive manner [22]. STEM hones cognitive, psychomotor, and affective domain; applies knowledge into technology; and trains students to design, develop, and utilize technology in daily activity [23]. STEM skills can aid students in connecting existing concepts to newly gained knowledge in every phase of 7E LC. Such a process can situate the learning to be centered on students [24], and make the learning context to be meaningful [25]. Therefore, STEM-integrated 7E LC is expected to be the most appropriate method to increase the quality of the learning process [26] so that students' CTS in the Temperature and Heat topic can improve considerably. This study aims to discover the influence, increase, and effect of 7E LC-STEM on students' CTS in the Temperature and Heat topic. 


\section{Method}

This research used Pre- and Posttest Design in a quasi-experiment [27]. The subject was 66 eleventh grade students in Senior High School Batu Indonesia, which were divided into Experiment $(n=30)$ and Comparison $(n=36)$ classes. The Experiment class was taught using STEM-Integrated 7E LC model and Comparison class was taught with 7E LC model. 7E LC consisted of seven phases [14], and the STEM integration aspect was conducted as follows [28]. The Elicit and Engage phases required students' pre-existing knowledge by using media or a case study. The Elicit phase involved the aspect of Science, while the Engage phase involved the aspects of Science and Engineering in STEM. In the Explore, Explain, Elaborate, and Evaluate phases, students endeavoured in the exploration of knowledge and concepts through observation, data gathering, hypotheses formulation, and knowledge implementation to solve a problem. The Explore phase involved all aspects of STEM. The Explain, Elaborate, and Evaluate phases involved aspects of Science, Engineering, and Mathematics. In the Extend phase, students expanded the result in the Evaluate phase and communicated their findings to train them to connect their acquired knowledge in daily practice. The Extend phase involved the aspects of Science, Technology, and Mathematics. The Engineering aspect is the most dominant in all amongst the seven phases. Engineering has seven steps, which are identifying the problem, information collecting to looking for possible solutions, choosing the best solution, designing and making, testing, modifying, and assessment [29]. The 7E LC class did some experiments while the 7E LC-STEM class did some experiments and produced two simple products.

The research instrument was students' Creative Thinking Skills Test with Cronbach's alpha reliability of 0.803 . Based on the characteristics of the Temperature and Heat topic and the opinions of Guilford and Torrance, this instrument consisted of four Creative Thinking Skills' indicators, which are Fluency (Flue), Flexibility (Flex), Originality (Origin), and Elaboration (Elab). The results were five categories, which are Not Creative (level 0), Almost Not Creative (level 1), Quite Creative (level 2), Creative (level 3), and Very Creative (level 4) [30]. This research used a data analysis technique with t-test and effect size [31], with N-gain $[32]$.

\section{Result and Discussion}

The pre-test data analysis of students' CTS mean (with criteria), and standard deviation are as follows: (28.50 (Almost Not Creative); 9.48) for Experiment class, and (24.17 (Almost Not Creative); 9.78) for Comparison class. From this result, it can be said that the level of CTS of Experiment class and Comparison class were similar. Further test showed that normality and homogeneous assumptions were satisfied in the pre-test data. After being analized with t-test, the result of Sig. $(2$-tailed $)=0.076$ was yielded, which shows that there's no difference between groups. It can be concluded from this that both classes had the same initial condition before the experiment. The change in CTS by the end of the learning process was solely caused by the different model treatments in the two classes.

The post-test data analysis of students' CTS mean (with criteria), and standard deviation are as follows: (74.50 (Creative); 6.99) for Experiment class, and (64.31 (Creative); 8.19) for Comparison class. It's shown that the Experiment class acquired a higher creative thinking skill level than the Comparison class. Normality and homogeneous assumptions were satisfied 
in the post-test data. The result of t-test analysis yielded Sig. (2-tailed) $=0.000$ which shows that there's a difference between groups. This indicates that the 7E LC-STEM learning in Experiment class resulted in a significantly higher level of students' CTS than 7E LC learning in Comparison class in the Temperature and Heat topic.

During the course of the study, both classes worked on 4 experiments and presented the results in class. However, the 7E LC-STEM class also worked on contextual problems by building two simple products as the solution, which are fire alarm and air conditioner. After the product's construction was completed, several activities were conducted, which are product testing, poster design, final presentation, and report writing. It's apparent that the product completion process made the students in Experiment class work on a higher number of activities than the Comparison class. Under the STEM setting, the product design completion altogether can be the means for the students to communicate their understanding of the concepts with one another [33]. The concepts which are usually learned separately can be used to solve the contextual problem in daily lives in STEM integration. This encourages students to keep on learning [34]. Other than that, STEM integration in learning can encourage the students to explore the topics that spark their interests and pursue what they want to do in the future, including their aspirations in the field of mathematics and science [35]. It can be concluded that, on the Temperature and Heat topic, the proposed 7E LC-STEM method can help to enhance CTS of students better than 7E LC method. This finding is in accordance with the result of the previous study with engineering STEM-based process in a learning approach, which was able to increase tenth grade students' CTS in the Equilibrium topic [36]. The worksheet which was used by students throughout the learning process was deemed effective in improving their creative thinking skills, especially with the STEM approach which was imbued within [37]. It's evident that STEM learning can improve creativity of students with the use of examples from real-life problems which can be encountered in person [38].

Students in both classes were successful in upgrading their level of CTS from Almost Not Creative at the beginning of the study to Creative at the end of the study. This means that there's an internal change within students in a sense that they're able to produce a novel and divergent solution which also includes conceptual understanding behind the use of mathematical equations [30]. This change was possible because both 7E LC-STEM and 7E LC classes were not conventional classes. In a conventional within, generally, when students are given problem description in a form of a story (without mathematical hints), they are more inclined to answer by constructing physics concept understanding through mathematical equations than to elaborate with verbal essays containing the relevant concepts [39].

$\mathrm{N}$-gain analysis was conducted on pre-test data and post-test data. Experiment class had $\mathrm{N}$-gain value of 0.64 which can be categorized as medium. Comparison class had N-gain value of 0.53 . If we compare the two values, it can be concluded that the increase of students' CTS in Experiment class was higher than the increase in Comparison class, which means that the purposed 7E LC-STEM learning can increase students' CTS better than 7E LC learning. It can be seen that this result supports the finding from the t-test result which was discussed previously. On one study about active students, the threshold of $\mathrm{N}$-gain value to be surpassed in learning is 0.48 [40] and it can be seen that both Experiment class and Comparison class had higher value than the threshold. Previous research about the STEM approach utilization to better students' CTS also support this finding [36]. The score of Comparison class' N-gain was also higher than the threshold because the learning used in the class was not a conventional method. Moreover, Learning Cycle was also proved to be an effective method to improve CTS of students [41]. 
$\mathrm{N}$-gain analysis was also done to the 4 indicators of CTS. The value of the $\mathrm{N}$-gain and the category are written on Table 1.

Table 1. The CTS' N-gain score of each indicator.

\begin{tabular}{cll}
\hline \multirow{2}{*}{ Indicators } & \multicolumn{2}{c}{ N-gain Classes (category) } \\
\cline { 2 - 3 } & Experiment & Comparison \\
\hline Flue & $0.71(\mathrm{H})$ & $0.60(\mathrm{M})$ \\
Flex & $0.68(\mathrm{M})$ & $0.43(\mathrm{M})$ \\
Origin & $0.67(\mathrm{M})$ & $0.51(\mathrm{M})$ \\
Elab & $0.59(\mathrm{M})$ & $0.50(\mathrm{M})$ \\
\hline
\end{tabular}

$\mathrm{H}=$ high; $\mathrm{M}=$ medium

It can be seen from Table 1 that the proposed 7E LC-STEM learning was successful in improving the indicators of CTS. Those indicators are, in the order of the highest to the lowest improvement, Flue, Flex, Origin, and Elab. This order is the same as the finding in previous research [41]. It's also apparent that the improvement in Experiment class was better than Comparison class on all indicators based on the N-gain of both classes. The Flue indicator had the highest N-gain on both Experiment and Comparison class. This is caused by students activity in class which required them to think and provide as many answers as possible for a real-life problem in the subtopic of heat transfer. However, the category of the N-gain in Experiment class (high) was a level higher than the Comparison class (medium) in this indicator. The reason for this is because the students in Experiment class was more active in working on a simple air conditioner as engineering product. Other thing that can be seen from Table 1 is that the N-gain category of the Experiment class in Flex and Origin indicators was higher than the category in Comparison class. The reason for this difference in level is because the students in Experiment class had an activity in which they had to make simple fire alarm as a product. The product which didn't exist before was proven valuable and was a result of a worthy invention, and the students had to work their creative side to produce the ideas of the product as a solution of a problem [42].

The N-gain score in the Elab indicator was the lowest for both classes. It means that students are still lacking in providing details and clear explanations of their ideas. Other research also found that students' skill in elaboration activity could only reach Quite Creative category [41]. This may be caused due to the fact that in learning, there's still not enough activity that trains the Elab indicator. In the learning process of both classes, each of the indicators Flue, Flex, and Origin, were trained in two phases. Those two phases are, in the order of execution, Engage-Evaluate, Elicit-Explain, and Explain-Elaborate. Meanwhile, the Elab indicator was only trained in one phase, which is called Extend. Therefore, there needs to be a continuous training and more amount of activity to develop students' creative thinking skills, especially the Elab indicator. For example, the Elab indicator can be developed initially by encouraging students to give as many questions as possible about daily phenomenons in the Elicit phase, by asking the students to solve the questions in the Explain phase, by further elaborating the solution in the Elaborate phase, and finally by finalizing the knowledge understanding about the phenomenon in the Extend phase.

Cohen's effect size analysis was done on the pair of Experiment-Comparison classes and yielded d value of 1.332 on the "Very Large" category of students' creative thinking skills. It means that the implementation effect of the proposed 7E LC-STEM had a "Very Large" 
impact on CTS compared with 7E LC method. Educators or teachers can implement 7E LCSTEM method as a strategy to improve CTS of their students. Not only to help students achieve better academics goals, CTS will also help students as individuals to contribute more in society by solving real-life problems that they might encounter [43].

Questionnaire was issued to the students of both classes after the experiment to gauge their response or preference towards the learning that they experienced. Students' response in the Experiment class showed that the proposed method was more well-received than the learning in Comparison class. The Experiment class received $91.3 \%$ and $87.7 \%$ response for the Agree and Strongly Agree answer. However, the results on the Comparison class was similar to the Experiment class. It means, either 7E LC-STEM or 7E LC can provide a comfortable learning environment for students. The reason for this is because both methods are very different from conventional method and provide more activity for students and demands more involvement from them. This is supported by the result in previous study which shows that students are more comfortable learning with Physics STEM Education Learning compared to learning with conventional learning method [44].

\section{Conclusion}

Based on the results and discussion, there's a difference between students' CTS in Experiment class and Comparison class. The average score of the Experiment class (74.50) was higher than the Comparison class (64.31). Thus, it can be concluded that 7E LC-STEM learning can make students gain significantly higher CTS than 7E LC learning. Both classes increased the skill from Almost Not Creative to Creative levels CTS on both classes was able to be improved in Medium category, but the indicators of CTS on Experiment class were improved better than Comparison class based on the $\mathrm{N}$-gain analysis. The value of $\mathrm{d}$ effect size of Experiment class was 1.332 (Very Large category) which shows that 7E LC-STEM had better impact than 7E LC regarding students' CTS. Students were very comfortable in both classes because they weren't conventional classes. However, students had a more positive response towards Experiment class than the Comparison class, which gained respectively $91.3 \%$ and $87.7 \%$ in Agree and Strongly Agree responses in the final questionnaire.

\section{References}

[1] Baser, M.: Effect of Conceptual Change Oriented Instruction on Students' Understanding of Heat and Temperature Concepts. Journal of Maltese Education Research Vol. 4(1), pp. 64-79 (2006)

[2] Alwan, A.A.: Misconception of heat and temperature Among physics students Procedia - Social and Behavioral Sciences Vol. 1(2), pp. 600-614 (2011)

[3] Chiou, G.L. and Anderson, O. R.: A study of undergraduate physics students' understanding of heat conduction based on mental model theory and an ontology-process analysis Science Education Vol 94(5), pp. 825-854 (2010)

[4] Kocakaya, S. and Gonen, S.: The Effects Of Computer-Assisted Instruction Designed According To 7e Model Of Constructivist Learning On Physics Student Teachers' Achievement, Concept Learning, Self-Efficacy Perceptions And Attitudes. Turkish Online Journal of Distance Education Vol. 11(3), pp. 206-224 (2010) 
[5] Thomaz, M.F., Malaquias, I.M., Valente, M.C. and Antunes, M.J.: An attempt to overcome alternative conceptions related to heat and temperature. Physics Education Vol. 30(1), pp. 19-26 (1995)

[6] Hafizah, E., Arif, H. and Muhardjito.: Pengaruh model pembelajaran anchored instruction terhadap penguasaan konsep dan kemampuan pemecahan masalah siswa kelas X. Jurnal Fisika Indonesia Vol. 52(18), pp. 8-12 (2014)

[7] Barrett, J.D., Peterson, D., Hester, K.S., Robledo, I.C., Day, E., Hougen, D. and Mumford, M.D.: Thinking About Applications: Effects on Mental Models and Creative Problem-Solving Creativity Research Journal Vol. 25, pp. 199-212 (2013)

[8] Boyaci, Ş.D.B and Atalay, N.: A scale development for 21st century skills of primary school students: A validity and reliability study. International Journal of Instruction Vol. 9(1), pp. 133-135 (2016)

[9] Piirto, J.: Creativity for 21 st century skills: How to embed creativity into the curriculum Rotterdam: Sense Publ. (2011)

[10] Athifah, D. and Syafriani : Analysis of students creative thinking ability in physics learning. IOP Conf. Series: Journal of Physics: Conf. Series 1185, 012116 (2019)

[11] Ritter, S.M. and Mostert, N.: Enhancement of Creative Thinking Skills Using a Cognitive-Based Creativity Training J Cogn Enhanc Vol. 1(3), pp. 243-253 (2017)

[12] Taufiq, M. and Hidayani, N.: Upaya Meningkatkan Keterampilan Berpikir Kreatif Siswa Melalui Model Pembelajaran Generatif Pada Kelas X SMA Negeri 1 Peusangan Selatan Konsep Perpindahan Kalor. Jurnal Pendidikan Almuslim Vol. 4(2), pp. 48-53 (2016)

[13] Sriatun, S., Ellianawati, E., Hardyanto, W. and Milah, I.L.: Analisis Kemampuan Berfikir Kreatif Siswa pada Praktikum Asas Black Berbasis Problem Based Learning dan Berbantuan Makromedia Flash. Physics Communication Vol. 2(1), pp. 70-75 (2018)

[14] Eisenkraft, A.: Expanding the 5E Model Science Teacher Vol. 70(6), pp. 56-59 (2003)

[15] Bybee, R.W., Taylor, J., Gardner, A., Van Scotter, P., Carlson Powell, J., Westbrook, A. and Landes, N.: The BSCS 5E instructional model: Origins and effectiveness. Colorado: Office of Science Education National Institutes of Health (2006)

[16] Bilgin, I., Coşkun, H. and Aktaş, I.: The Effect of 5E Learning Cycle on Mental Ability of Elementary Students. Journal of Baltic Science Education Vol. 12(5), pp. 592-607 (2013)

[17] Akinwumi, M.O. and Bello, T.O.: Relative Effectiveness of Learning-Cycle Model and InquiryTeaching Approaches in Improving Students' Learning Outcomes in Physics. Journal of Education and Human Development Vol. 4(3), pp. 169-180 (2015)

[18] Jang, H.: Identifying 21st Century STEM Competencies Using Workplace Data. Journal of Science Educational Technology Vol, 25(2), pp. 284-301 (2016)

[19] Hestenes, D.: A role for physicists in STEM education reform. American Journal of Physics Vol. 83(2), pp. 101-103 (2015)

[20] Han, S., Capraro, R. and Capraro, M.M.: How science, technology, engineering, and mathematics (STEM) project-based learning (PBL) affects high, middle, and low achievers differently: The impact of student factors on achievement. International Journal of Science and Mathematics Education 135 1089-1113 (2015)

[21] National STEM Education Center.: STEM education network manual. Bangkok: The Institute for the Promotion of Teaching Science and Technology (2014)

[22] Ercan, S., Altan, E.B., Taştan, B. and Dağ, İ.: Integrating GIS into Science Classes to Handle STEM Education. Journal of Turkish Science Education Vol. 13(10), pp. 30-4330 (2016)

[23] Kapila, V. and Iskander, M.: Lessons learned from conducting a K-12 project to revitalize achievement by using instrumentation in Science Education. Journal of STEM Education Vol. 15(1), pp. 46-51 (2014)

[24] Ostler, E.: 21st Century STEM Education: A Tactical Model for Long-Range Success. International Journal of Applied Science and Technology Vol. 2(1), pp. 28-33 (2012)

[25] Brophy, S., Klein, S., Portsmore, M. and Rogers, C.: Advancing engineering education in P-12 classrooms. Journal of Engineering Education Vol. 97(3), pp. 369-387 (2008) 
[26] Guzey, S.S., Harwell, M., Moreno, M., Peralta, Y. and Moore, T.J.: The Impact of Design-Based STEM Integration Curricula on Student Achievement in Engineering, Science, and Mathematics. Journal of Science Education and Technology Vol. 26(2), pp. 207-222 (2017)

[27] Creswell, J.W.: Educational research: planning, conducting, and evaluating quantitative and qualitative research. Boston: Pearson Education, Inc. (2012)

[28] Dass, P.M.: Teaching STEM Effectively with the Learning Cycle Approach K-12. STEM Education Vol. 1(1), pp. 5-12 (2015)

[29] Reeve, E.M.: Science, Technology, Engineering \& Mathematics (STEM) Education is Here to Stay Retrieved from http://www.stemedthailand.org/wp-content/uploads/2015/08/STEM-Educationis-here-to-stay.pdf (2015)

[30] Siswono, T.Y.E.: Level of student's creative thinking in classroom mathematics Educational. Research and Review Vol. 6(7), pp. 548-553 (2011)

[31] Morgan, G.A., Leech, N.L., Gloeckner, G.W. and Barrett, K.C.: SPSS for Introductory Statistics Use and Interpretation. London: Lawrence Erlbaum Associates (2004)

[32] Hake, R.: Interactive-engagement vs traditional methods: a six-thousand-student survey of mechamics test data for introductory physics courses. Am. J. Phys. Vol. 66(1), pp. 64-74 (1998)

[33] Torlakson, T.: INNOVATE: A Blueprint for Science, Technology, Engineering, and Mathematics in California Public Education. California: California Department of Education (2014)

[34] Guthrie, J.T., Allan, W. and Clare, V.: Effects of integrated instruction on motivation and strategy use in reading. Journal of Educational Psychology Vol. 92(2), pp. 331-41 (2000)

[35] Stohlmann, M., Moore, T.J. and Roehrig, G.H.: Considerations for teaching integrated STEM education Journal of Pre-College Engineering. Education Research (J-PEER) Vol. 2(2), pp. 1-28 (2012)

[36] Mathiphatikul, T., Bongkotphet, T. and Dangudom, K.: Learning management through engineering design process based on STEM education for developing creative thinking in equilibrium topic for 10th grade students. IOP Conf. Series: Journal of Physics: Conf. Series 1157, 032015 (2019) [37] Prakoso, A.S., Suwarma, I.R and Purwanto.: Profil Keterampilan Berpikir Kreatif Siswa pada Pembelajaran IPA Berbasis STEM. PROSIDING SNIPS. July, 21-22 (2016)

[38] Kelley, T.R. and Knowles, J.G.: A conceptual framework for integrated STEM education International. Journal of STEM Education Vol. 3(11), pp. 1-11 (2016)

[39] Hung, W. and Jonassen, D.H.: Conceptual Understanding of Causal Reasoning in Physics. International Journal of Science Education Vol. 28(13), pp. 1601-1621 (2006)

[40] Jackson, J., Dukerich, L. and Hestenes, D.: Modeling instruction: an effective model for science education. Science Educator Vol. 17(1), pp. 10-17 (2008)

[41] Saputro, E.H., Rahayu, Y.S. and Hidayat, M.T.: Pengembangan Perangkat Pembelajaran IPA Berbasis 5E Learning Cycle untuk Melatih Kemampuan Berpikir Kreatif Siswa SMP JPPS. Jurnal Penelitian Pendidikan Sains Vol. 5(2), pp. 1001-1008 (2016)

[42] Sarkar, P. and Chakrabarti, A.: Assessing design creativity Design Studies 324 348-383 (2011)

[43] Mokaram, A.A.K., Al-Shabatat, A.M., Fong, S.F. and Andaleeb, A.A.: Enhancing Creative Thinking through Designing Electronic. Slides International Education Studies Vol. 4(1), pp. 39-43 (2011)

[44] Teevasuthonsakul, C., Yuvanatheeme, V., Sriput, V. and Suwandecha, S.: Design Steps for Physic STEM Education Learning in Secondary School IOP Conf. Series: Journal of Physics: Conf. Series 901012118 (2017) 